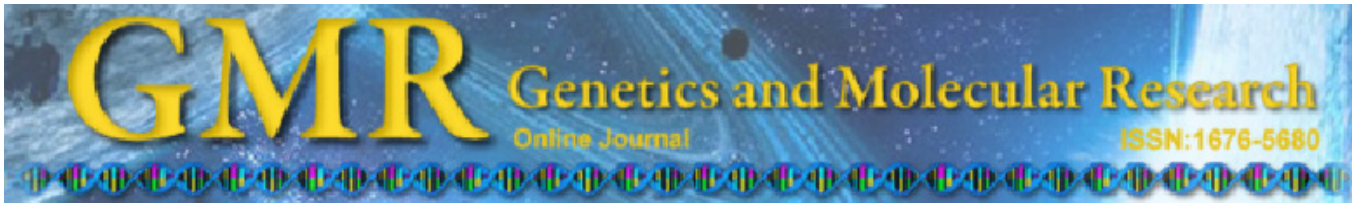

Methodology

\title{
A rapid and inexpensive method for isolation of total DNA from Trichoderma spp (Hypocreaceae)
}

\author{
J.C. Vazquez-Angulo, V. Mendez-Trujillo, D. González-Mendoza, \\ A. Morales-Trejo, O. Grimaldo-Juarez and L. Cervantes-Díaz \\ Instituto de Ciencias Agrícolas, Universidad Autónoma de Baja California, \\ Baja California, México \\ Corresponding author: D. González-Mendoza \\ E-mail: daniasaf@gmail.com \\ Genet. Mol. Res. 11 (2): 1379-1384 (2012) \\ Received September 5, 2011 \\ Accepted February 16, 2012 \\ Published May 15, 2012 \\ DOI http://dx.doi.org/10.4238/2012.May.15.8
}

\begin{abstract}
Extraction of high-quality genomic DNA for PCR amplification from filamentous fungi is difficult because of the complex cell wall and the high concentrations of polysaccharides and other secondary metabolites that bind to or co-precipitate with nucleic acids. We developed a modified sodium dodecyl sulfate/phenol protocol, without maceration in liquid nitrogen and without a final ethanol precipitation step. The $\mathrm{A}_{260 / 280}$ absorbance ratios of isolated DNA were approximately $1.7-1.9$, demonstrating that the DNA fraction is pure and can be used for analysis. Additionally, the $A_{260 / 230}$ values were higher than 1.6, demonstrating negligible contamination by polysaccharides. The DNA isolated by this protocol is of sufficient quality for molecular applications; this technique could be applied to other organisms that have similar substances that hinder DNA extraction. The main advantages of the method are that the mycelium is directly recovered from culture medium and it does not require the use of expensive and specialized equipment.
\end{abstract}

Key words: Genomic DNA extraction; Trichoderma; Filamentous fungi 


\section{INTRODUCTION}

Mexicali Valley is located in the District of Rural Development 002, which covers the municipalities of Mexicali and San Luis Rio Colorado, Sonora. Its arable irrigated area is 210,930 hectares. A total of 15,177 people work in agriculture in the Mexicali Valley, producing mainly cotton, wheat, alfalfa, and vegetables (Neir and Campana, 2007). The use of several pesticides in horticulture production can affect the heath of ecosystems. One of the most promising possibilities for the reduction of pesticide use is the application of microorganisms such as Trichoderma spp. These fungi are important for the control of soil- and seed-borne fungal diseases and also enhance plant growth and productivity in several crop plants (Kubicek et al., 2001). Our laboratory has isolated native Trichoderma species from Mexicali Valley soils that demonstrate the capability to grow in a wide range of temperatures and antagonize plant pathogens, using lignocellulosic materials for growth and for antibiosis and hyperparasitism (data not shown). In this sense, the isolation of pure DNA is crucial for the study of gene expression in this filamentous fungus because it is a prerequisite for several molecular biology techniques, including gene isolation with polymerase chain reaction (PCR), Southern blot, and the construction of DNA libraries. A variety of methods are currently available for the isolation of genomic DNA from filamentous fungi (Plaza et al., 2004; Melo et al., 2006), and although the quantity and quality of DNA obtained with these methods is generally satisfactory, the techniques are time-consuming and, therefore, unsuitable for analyses involving a large number of samples. Additionally, the DNA extraction from filamentous fungi has been described as somewhat complicated: most of the available protocols include the growth of mycelia in a liquid culture followed by maceration in liquid nitrogen and, usually, additional lysis steps such as mechanical disruption or sonication (AlSamarrai and Schmid, 2000). Therefore, the objective of this study was to develop an easy and rapid protocol for the isolation of good-quality total DNA from filamentous fungi such as Trichoderma biomass.

\section{MATERIAL AND METHODS}

\section{Fungal material}

Trichoderma strains ICA 1 and $2\left(10^{5}\right.$ spores, respectively) were inoculated and grown on potato dextrose broth at $28^{\circ} \mathrm{C}$ for $48 \mathrm{~h}$. Biomass (mycelia) grown in liquid medium was collected via filtration with a Millipore apparatus, and approximately $300 \mathrm{mg}$ of each fungal mycelium was transferred to a $1.5-\mathrm{mL}$ microtube and stored at $-80^{\circ} \mathrm{C}$ until use (Figure 1).

\section{DNA extraction buffer and solutions}

The tubes and bottles were treated with $0.1 \%$ diethyl pyrocarbonate solution at $37^{\circ} \mathrm{C}$ overnight, autoclaved twice at $121^{\circ} \mathrm{C}$ for $20 \mathrm{~min}$, and then dried at $100^{\circ} \mathrm{C}$ before use. Tips used for RNA extraction were DNase and RNase-free (Axygen ${ }^{\circledR}$, USA). The extraction buffer was $3 \%$ sodium dodecyl sulfate (w/v) containing $0.5 \mathrm{mM}$ ethylenediaminetetraacetic acid, $1.0 \mathrm{mM}$ $\mathrm{NaCl}$, and $0.1 \mathrm{mM}$ hydroxymethyl-hydrochloride (Tris-HCl, $\mathrm{pH} 8.0$ ). Additionally, a mixture of chloroform/phenol $(1: 1, \mathrm{v} / \mathrm{v})$ was also prepared. 


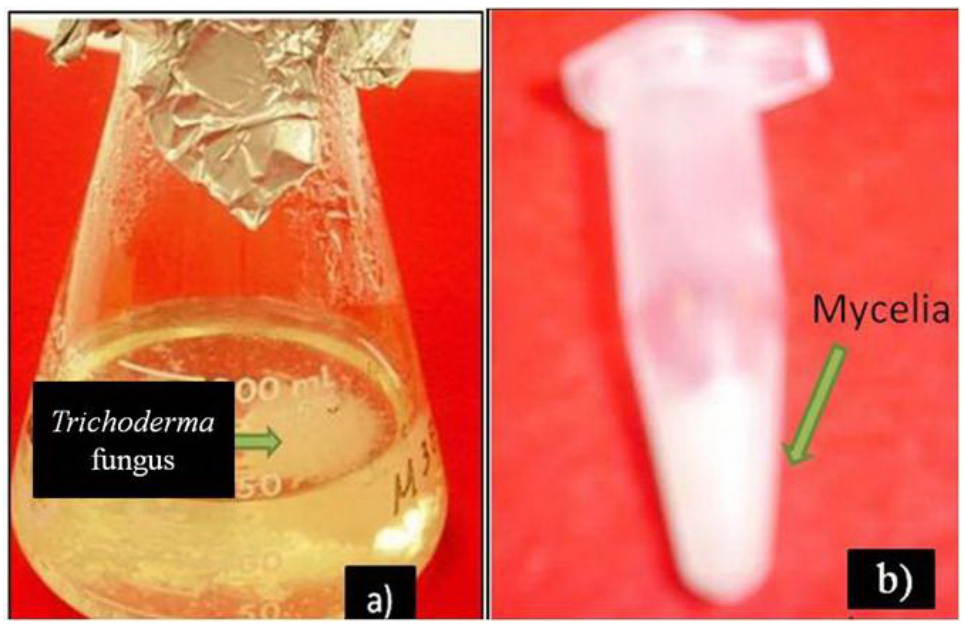

Figure 1. Trichoderma grown in liquid medium (a) and fungal mycelium collected in a 1.5-mL microtube (b).

\section{DNA extraction procedure}

Extraction buffer $(0.25 \mathrm{~mL})$ was added to $300 \mathrm{mg}$ of each fungus mycelium and shaken vigorously for $20 \mathrm{~s}$. Then, $0.25 \mathrm{~mL}$ chloroform-phenol mix was slowly added and incubated at $65^{\circ} \mathrm{C}$ for $5 \mathrm{~min}$. The mixture was centrifuged at $11,000 \mathrm{~g}$ at $4^{\circ} \mathrm{C}$ for $5 \mathrm{~min}$. The supernatant $(300 \mu \mathrm{L})$ was transferred to a new microtube, and 1-fold volume of cold absolute isopropanol was added and mixed thoroughly to precipitate total DNA at $-20^{\circ} \mathrm{C}$ for $30 \mathrm{~min}$. The mixture was then centrifuged at $11,000 \mathrm{~g}$ for $6 \mathrm{~min}$ at $4^{\circ} \mathrm{C}$. The supernatant was discarded, and the pellet was resuspended in $0.03 \mathrm{~mL}$ diethyl pyrocarbonate-treated MiniQuantum (deionized) water and stored at $-80^{\circ} \mathrm{C}$ for further use. Concentration, yield, and quality control indices based on absorbance readings at 230, 260, and $280 \mathrm{~nm}\left(\mathrm{~A}_{260 / 280}\right.$ and $\mathrm{A}_{260 / 230}$ ratios) were carried out with $3 \mu \mathrm{L}$ resuspended total DNA. Five microliters of total DNA solution was loaded onto $1 \%$ agarose gel, which was stained with ethidium bromide and electrophoresed to visualize DNA under ultraviolet light.

\section{PCR analyses}

Specific DNA of each fungus was amplified using PCR with Taq DNA polymerase (Invitrogen, CA, USA) according to manufacturer instructions. The PCR analysis was performed according to the method described by Gonzalez-Mendoza et al. (2008), and $2 \mu \mathrm{L}$ DNA was used as the PCR template. To assess the suitability of isolated DNA, PCRs with equal amounts of DNA were performed using cytochrome P450 (CyP450) gene primers (5'-CACCAGATTCTTGTTGATGC-3' and 5'-GTCTCTTTCTACACTCATTACC-3'). PCR analyses were carried out using the following protocol: $95^{\circ} \mathrm{C}$ for $7 \mathrm{~min}(1 \mathrm{cycle}), 50^{\circ} \mathrm{C}$ for 1 min, and $72^{\circ} \mathrm{C}$ for $1 \mathrm{~min}$ ( 35 cycles). The quality of the PCRs was monitored on $1.5 \%$ Trisacetate-ethylenediaminetetraacetic acid-agarose gel, and bands were visualized via staining with ethidium bromide. Images were captured and stored with a Kodak Electrophoresis Documentation and Analysis System. 


\section{RESULTS AND DISCUSSION}

The problems encountered in the isolation and purification of DNA, especially from Trichoderma spp, include degradation of DNA owing to endonucleases and the presence of inhibitor compounds such as secondary metabolites that can reduce yield and purity by binding covalently with the extracted DNA. In this study, we adapted a rapid RNA isolation method for plants (Gonzalez-Mendoza et al., 2008) by combining DNA isolation with chemical reagent digestion without mechanical shearing to lyse the hyphae of Trichoderma strain ICA 1 and 2. The isopropanol step allowed effective precipitation of DNA, rendering it more stable at $-20^{\circ} \mathrm{C}$ at $30 \mathrm{~min}$. In this sense, the results of our study agree with those of Padmalatha and Prasad (2006) who also observed the importance of a lower precipitation temperature $\left(-20^{\circ} \mathrm{C}\right)$. In this study, we also found that washing the pellet twice with $75 \%$ ethanol and centrifuging at $10,000 \mathrm{~g}$ at $4^{\circ} \mathrm{C}$ for $5 \mathrm{~min}$ produced poor results (data not shown). Therefore, we eliminated this step. Conversely, a salt concentration $(1 \mathrm{mM} \mathrm{NaCl})$ was introduced in the buffer extraction to avoid preventing or diminishing the dissolution of polysaccharides during the extraction step. In all cases, we obtained robust yields of high-quality genomic DNA (Figure 2). The $\mathrm{A}_{260 / 280}$ ratio was 1.8 , suggesting that the DNA fraction was pure and may be used for further analysis. In all samples, the $\mathrm{A}_{260 / 230}$ ratios were higher than 1.6, suggesting negligible contamination by polysaccharides.

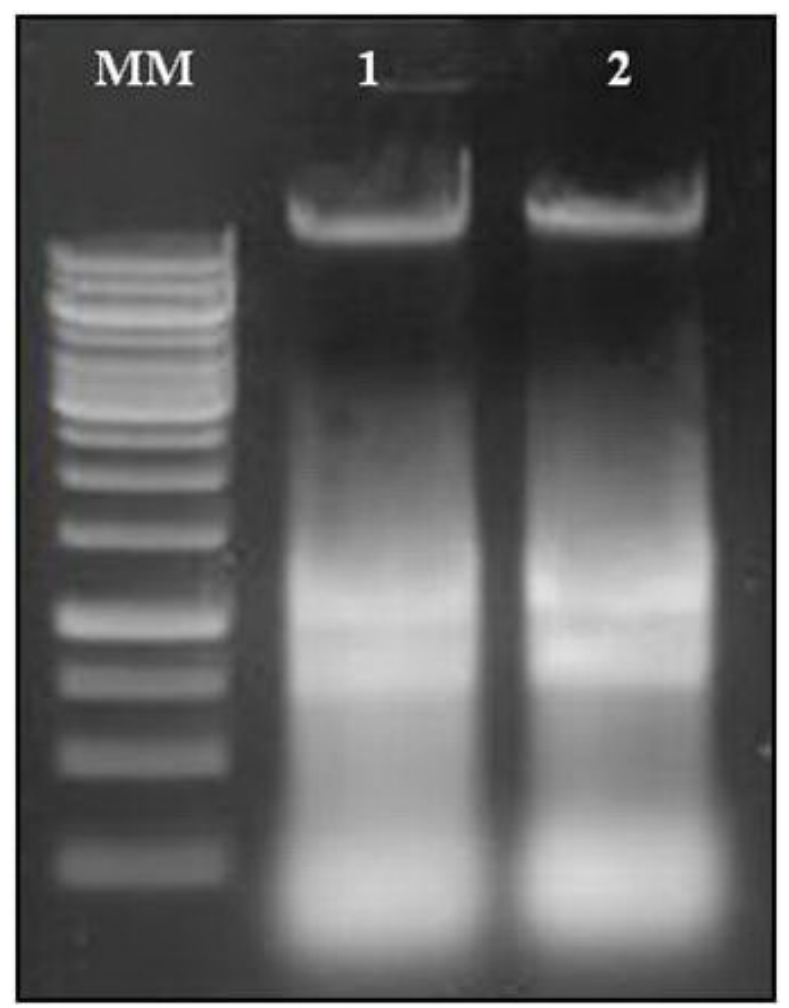

Figure 2. Gel electrophoresis of the total DNA extracted from Trichoderma spp. Lanes 1 and 2 = DNA isolated from Trichoderma spp strain ICA 1 and 2, respectively; lane $M M=$ molecular marker. 
To confirm the purity of the DNA and its usefulness for basic molecular analysis, we performed PCR amplification of a fragment of the CyP450 gene present in both fungi. The amplification produced a single band of approximately $300 \mathrm{bp}$ specific to the CyP450 gene (Figure 3).

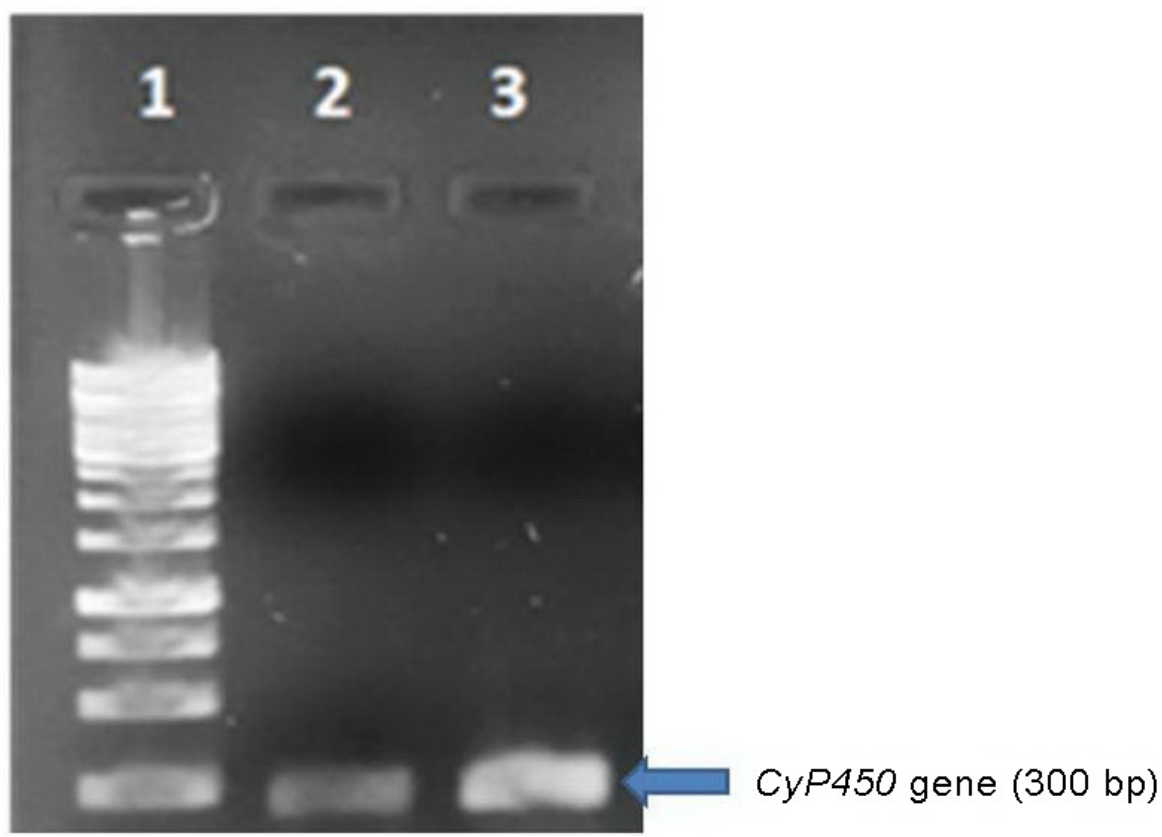

Figure 3. Agarose electrophoresis of the RT-PCR products. Lane $1=$ DNA marker; lanes 2 and $3=$ CyP450 gene, $300 \mathrm{bp}$.

One of the advantages of our procedure is the elimination of maceration and pellet washing with ethanol, which reduces sample handling and minimizes contamination risks between samples for molecular assays. Additionally, this protocol shows that the DNA produced in our laboratory is simple and fast, is of high quality, and can be used reliably in DNA manipulation and PCR-based techniques for fungus (e.g.; Trichoderma spp) even in low-technology laboratories.

\section{ACKNOWLEDGMENTS}

Research supported by the Consejo Nacional de Ciencia y Tecnologia (CONACyT)

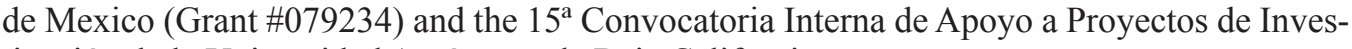
tigación de la Universidad Autónoma de Baja California.

\section{REFERENCES}

Al-Samarrai TH and Schmid J (2000). A simple method for extraction of fungal genomic DNA. Lett. Appl. Microbiol. 30: 53-56.

Gonzalez-Mendoza D, Moreno AQ and Zapata-Perez O (2008). An improved method for the isolation of total RNA from Avicennia germinans leaves. Z. Naturforsch. C 63: 124-126. 
Kubicek CP, Mach RL, Peterbauer CK and Lorito M (2001). Trichoderma: from genes to biocontrol. J. Plant Pathol. 83: 11-23.

Melo SC, Pungartnik C, Cascardo JC and Brendel M (2006). Rapid and efficient protocol for DNA extraction and molecular identification of the basidiomycete Crinipellis perniciosa. Genet. Mol. Res. 5: 851-855.

Neir AM and Campana ME (2007). The peaceful resolution of U.S.-Mexican transboundary water disputes. EPSJ 2: $42-$ 48.

Padmalatha K and Prasad MNV (2006). Optimization of DNA isolation and PCR protocol for RAPD analysis of selected medicinal and aromatic plants of conservation concern from Peninsular India. Afr. J. Biotechnol. 5: 230-234.

Plaza GA, Upchurch R, Brigmon RL, Whitman WB, et al. (2004). Rapid DNA extraction for screening soil filamentous fungi using PCR amplification. Pol. J. Environ. Stud. 13: 315-318. 